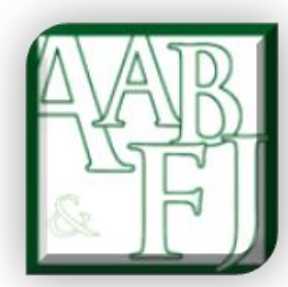

\title{
Taxation and the American Revolution
}

\author{
John Passant ${ }^{1}$
}

\begin{abstract}
This article looks at the interrelationship between revolution and tax in the context of the American Revolution. It examines the role of ordinary people in demanding, among other things, as part of wider demands for democracy and equality, no taxation without representation.

The article aims to reintroduce the neglected notions of class and class struggle into current discussions and debates about tax and history, putting the people back into academic narratives about the history of taxation and to their place as political actors on history's stage.
\end{abstract}

JEL Classification: H20, K34

Keywords: Tax, History, USA, American Revolution, Marx, no taxation without representation

\footnotetext{
${ }^{1}$ Lecturer, Business School, Charles Darwin University; PhD candidate, School of Politics and International Relations, ANU. This research is supported by an Australian Government Research Training Program (RTP) Scholarship.
} 


\section{Introduction}

This paper examines taxation and the American Revolution. Taxation sparked or was a major contributor to that revolution. Not only that, but once the spark had fired up the masses, the quest for democracy that the revolution threw up was inextricably linked to taxation. 'No taxation without representation' perfectly captures this interrelationship.

Tax issues are class issues. As John Passant (2016, p.68) has written:

[T] ax is a key element in history, a reflection of the contradictions in class society and a spark for rebellion by both elements of the ruling class, or hostile brothers, (Marx 1974; Moseley 2002) and by the exploited and oppressed - in Marxist terms those who produce the economic wealth of society for the ruling class - the peasants, artisans, workers and others impacted by the taxes and more generally by their role and position in society.

The tax and class issues I look at in this article occur in the context of a society undergoing massive economic and political change. This includes transition from foreign rule to the rule of a home-grown elite as a result of the solidification and expansion of capitalism and its twin at the time, slavery, in the American colonies.

The article looks at the ongoing changes and battles these developments created from the point of view of the exploited and oppressed classes in the US, the common people of the 'lower sort' (Rosswurm, 1987). To this end, and with that class perspective in mind, I look at tax and the American Revolution. It is a people's history, adopting the general historical approach of the likes of Zinn (2003) and Harman (2008) to understand history from below. My examination leads me to conclude that class and class struggle - in other words, the role of the lower sort - is the key to understanding the American Revolution. Tax is an important element in that class history and understanding.

\section{Tax and the American Revolution}

Tax was the handmaiden of the Revolution, in particular in the conflict over whether the British Parliament or the American colonies had the power and right to tax (Countryman 2003). This was a rebellion of both the American elites and the common people against British rule (Raphael 2002; Zinn 2003). However, it was also a rebellion by the lower sort against the American elite; inchoate and episodic, perhaps, but nevertheless as real as that against the British (Raphael 2002; Zinn 2003).

One of the cries of the American revolutionists - and one that they took, real or imagined, from previous tax-sparked rebellions such as the Magna Carta and the English Civil War (Passant 2016) - was no taxation without representation (Miller 1959, p. 88-90; Ross 2004, p. 32). Yet like much of the American Revolution there is a complexity to this that ignores a deeper reality. (For a discussion of appearance and reality in a tax context, see Passant (2016).) That deeper reality is the class nature of the demand and the fear the elites had of the lower classes. The men of property gambled in joining with the lower orders that they could further their own limited political revolution and control the revolution in their interests and not those of the mass of people driving the revolution. 
'[A]ll men are created equal', claimed the Declaration of Independence (US 1776). Yet a majority of the 56 men who signed the document owned slaves (Young et al. 2012, p. 3). For them, 'all men' meant not all men (and certainly not women: Zinn (2003, p. 102) but a specific section of American white men - big property owners, including those who owned black men, women and children. As Zinn (2003, p.73) says, this was not a deliberate omission of women. They were invisible as political and economic actors to the framers of the Declaration. On the other hand, women played an important role in the Revolution (Zinn 2003, p. 109-11).

The founders feared the lower classes. Harking back to the enemies of change in the English revolution, they labelled those who argued for democracy and equality as 'levellers' and used the word 'democrats' as an insult (Young et al. 2012, p. 3). Their constitution was framed to prevent too much democracy. As these authors note, 'With few exceptions, the honourable gentlemen who drafted and signed our two founding documents opposed popular democracy and social equity' $(2012$, p. 3). They describe this as a 'rich dialectic in which men in power chose to accommodate or repress threats from below, [which] was central to the forming of the nation' (2012, p. 4).

There is more to it than that, as Young et al. (2012) themselves recognise. The men in power were rich white men. The deeper dialectic was the revolutionary movements from below which challenged, or had the potential to challenge, their rule. Further, contrary to popular history, filtered through the prism of the victory of the American ruling class in the Revolution, the real revolutionary founders were not the elite who wrote the founding documents but common artisans, farmers, labourers, slaves who had escaped slavery, women fighting for equality, persecuted religious minorities, soldiers with democratic ideals, Native Americans and the selfproclaimed democrats who turned the elite's insult about democrats on its head (2012, p. 11). These were the true radicals, wanting root changes to the social and political structures $(2012, \mathrm{p}$. 4-5).

Their impact was profound. As Young et al. (2012, p. 5) note, 'Each of these rebels, radicals, and reformers moved the American Revolution in some direction the traditional founders did not want to take, extending it farther and deeper than a separation from the British Empire. They made the Revolution more revolutionary' (2012, p. 5). The dialectic of action and reaction however saw the elite, threatened by the classes below, respond for example over the period 1787 to 1789 in the drafting, ratification and implementation of a new Constitution to replace the inadequate initial one. This new Constitution was 'a more perfect union [to prevent] an excess of democracy' (2012, p. 3).

The fear the elite had during and after the Revolution was that the underclasses would take up the very slogans of freedom and equality the elite were proclaiming for themselves. As Howard Zinn (2003, p. 57-8) puts it:

[The] upper classes, to rule, needed to make concessions to the middle class, without damage to their own wealth or power, at the expense of slaves, Native Americans, and poor whites. This bought loyalty. And to bind that loyalty with something more powerful even than material advantage, the ruling group found, in the 1760s and 1770s, a wonderfully useful device. That 
device was the language of liberty and equality, which could unite just enough whites to fight a Revolution against England, without ending either slavery or inequality.

There is another related aspect to this. This was essentially a political revolution in which one section of the hostile brothers, the home-grown American capitalist class, especially the big industrialists and property and slave owners, was fighting against colonial capital and colonial rule for possession of the state and states, and fighting for the establishment of a unified American capitalist state. This sector of the populace, the constituent elements of the capitalist class, united against the working class but fought each other for a share of the surplus value workers create (Passant (2015, p. 265-6); Marx (1974, p. 253); Moseley 2012)).

As Harman (2008, p. 265-6) notes, this national unity of the American elite against Britain was a late development forced on them by the actions of the colonial ruler. Even as late as 1776 not all the future revolutionaries argued for an independent United States.

Given all this, the loyalty of the lower classes to the Revolution could not always be guaranteed. Where class and nationalism intersect in a crisis such as a national revolution, class has the potential to break the boundaries of nationalism.

If that movement of the lower classes is thwarted, some of the oppressed and exploited may support the enemy of their immediate enemy. So it was in the American Revolution. For example, most Native Americans fought with the British (Zinn 2003, p. 87). This was because the British had reached Settlement with them in the Royal Proclamation of 1763 not to expand beyond the Appalachians. Local US capital chaffed at this restriction on its expansion (Zinn 2003 , p. 87). For slaves and freed slaves, while 5000 fought for the Revolution, 30,000 fought for the British (Nash (1996, p. xix); Franklin (1947, p. 133); Zinn (2003, p. 88)). This at first seemingly bizarre result is explicable by the fact that the British offered slaves their freedom if they fought for them (Zinn 2003, p. 88). It was the poorest Americans who did the fighting for the revolution (Zinn 2003, p. 77). Its generals however were from the ruling class. For example George Washington, a capitalist farmer, was the richest man in the United States (Zinn 2003, p. $85)$.

An important component of the siren song of liberty and equality was 'no taxation without representation.' The coupling of representation and taxation, drawing on the Magna Carta and the left in the English Civil War (Passant 2016), reflected a similar process to that which sparked the Magna Carta. The 'thuggish barons' of the US in the 1760s and 1770s were eventually forced to fight for control of the state that was taxing them, or more precisely replace that state with a state of and for national capital (slave holders in the South and manufacturing in the North and big property holders more generally). They wanted their national class and its various interests not just represented but in control. British political rule prevented that.

Taxation was clearly one of the major sparks for the rebellion that became the American Revolution. As the US Office of the Historian (n.d.) says: 'The American Revolution was precipitated, in part, by a series of laws passed between 1763 and $1775 \ldots$ regulating trade and taxes.' The funding of wars such as the Seven Years' War, the desire to control the colonies, the push from within Britain to reduce taxes on key local constituencies and by corollary to tax the American colonies' wealth and its increasing income (Miller 1959, p. 88-90), all contributed to punishing taxes being levied on the colonies. 
The treaty of Paris ended the Seven Years' War in 1763. According to the British Library (n.d.), the war was 'also known as the French and Indian War in North America. France ceded all mainland North American territories, except New Orleans, in order to retain her Caribbean sugar islands. Britain gained all territory east of the Mississippi River; Spain kept territory west of the Mississippi, but exchanged East and West Florida for Cuba.'

The taxes raised the question of democratic representation. As Michael L. Ross (2004, p. 232) says:

The final declaration of the Stamp Act Congress of 1765 - an ad hoc assembly to which nine of the thirteen colonial governments sent their representatives - asserted:

That it is inseparably essential to the Freedom of a People, and the undoubted Right of Englishmen, that no taxes be posed upon them, but with their own consent, given personally, or by their Representatives.

The Declaration of Independence cited the fact that King George had 'impos(ed) taxes on us without our consent' as one of the Revolution's main causes (Ross 2004, p. 232).

However, to step back a little to understand why the British government did this, the Americans were not the first target of the British state for revenue for its wars and colonial governance and expansion. The first point of attack by the British Parliament was its own people. This had two components. Parliament taxed the landowners - the squires as Miller calls them - more highly than it taxed merchants (Miller 1959, p. 87). As this proved inadequate in terms of revenue, and provoked real anger and potential rebellion from the powerful landholders, the British State looked to slug its own working class and other lower classes. The new taxes which fell on both the squires and the poor and labouring classes, included stamp duties, window taxes and excise taxes on wine and cider, and beer (Miller 1959, p. 87).

Apart from the stamp duties, the other new taxes on its own citizens were not so well accepted, perhaps because they related among other things to the staple alcoholic drinks of the squires and the labourers. For example, during the Seven Years' War, as well as a tax on the drinks of the large landowners - wine and cider - Pitt also imposed an additional duty on beer. The government calculated that the average hardworking Londoner drank four quarts of beer a day and anticipated an increase in revenue (Miller 1959, p. 87). These drink taxes provoked the landed gentry and the labouring classes across the country. The government withdrew them in light of the protests and uproar. It was a lesson the American colonies learnt well when the British Parliament attempted to tax the consumption of the colonialists.

After the rebellions against taxes on its own citizens, the British Parliament imposed a range of taxes on the American colonies without their approval. These taxes were designed to pay for the Seven Years' War, to pay for the cost of colonisation, to reduce taxes on the squires in Britain and to control trade for the benefit of British merchants (Miller 1959, p. 88-90). So it was that the British Parliament in 1764 imposed on its American colonies a tax on molasses, the raw sugar used in making rum, in 1765 a stamp tax on legal documents, newspapers and pamphlets British Library (n.d.), a Quartering Act which imposed the cost of British troops in America on the colonies and then a tax on imports in 1767 (Harman 2008, p. 267). 
These taxes provoked widespread anger and rebellion among Americans, sometimes not just against the British but against the rich strata in American society. The Stamp Act produced one such class rebellion. Because the tax applied to all legal documents, newspapers and pamphlets it was almost self-executing. Without a stamp, a document had no legitimacy or standing in the courts. The tax itself was an attempt by the British to tax the people of the colonies to pay for war against the French. In other words, colonialists were to pay for the expansion of the British Empire (Zinn 2003, p. 61).

The colonies responded. From 1767 to 1770 they went on a tax strike (Rees 1999). In Boston in 1767 mass anger broke out into riots of the poor which swept the city (Rees 1999, p. 65). The protesters focused not just on the British but also rich Americans.

The economic and political inequality in the city at this time was stark. The top ten per cent of the city's taxpayers held almost two-thirds of all the taxable wealth. The bottom 30 per cent had no taxable property at all. Those 30 per cent, because they had no property, could not vote. Neither could women, blacks or Native Americans (Zinn 2003, p. 65). In light of the anger and protests, the British withdrew the Stamp Act, but followed it with the Townshend Acts, which imposed tax in 72 items, and included changes to the tea tax (Norquist 2012). Eventually these too were withdrawn in the face of popular discontent, except for the tax on tea (Harman 2008). The British kept the tax on tea 'to make the point that the crown could tax when it chose to do so'(Norquist 2012). Tax was used as an instrument of rule and a message of servitude.

The rich white male leaders of the independence movement wanted to use lower class agitation against the British, but did not want to call these demons from below onto themselves. It was a delicate balancing act but one which the American ruling class, after learning the lessons of the Boston riots, proved more than capable of doing. Their emphasis became on peaceful protest and not 'mob rule' (Zinn 2003, p. 65-66), and the language of democracy and liberty (but not its actuality before or after the revolution for the majority of Americans) plus highlighting the undemocratic and tyrannical rule of the British.

A boycott of British goods was one way the colonialists resisted British taxes and control. The elite were ambivalent and wavered, in part because they benefited from the trade. The middle class supported it but were trapped in their own timidity. The poor and exploited classes were enthusiastic. So it was that in 1773, as part of direct action to support the tea boycott, a group of one hundred men, dressed as Native Americans, with thousands of protesters onshore supporting them, boarded an East India Company ship and threw the tea it was bringing in overboard (Harman 2008, p. 269). 'Respectable' leaders condemned the action but this was soon lost in the British response to the Boston Tea Party actions - repression. The rebellion was no longer just about tax. It was about both the heavy handedness of London, and the lack of representation. It raised the question, as Jefferson (1774) put it, 'whether 160,000 electors in the island of Great Britain give law to four million in the states of America.'

The revolution was building. The various groups that sprung up before and during the American Revolution reflected in part the differences of class cloaked in the unity of nation. Those agitating for revolution against the British included not just the middle class but the 'lower sort' 
(Rosswurm 1987). Their more radical agitation drove the revolution forward and bought with them the ruling classes.

There is a thread in US history at this time of local organising committees, made up of various labouring classes, actually meeting and deciding democratically on what was to be done. Thus, while the Continental Congress of the middle classes supported a new boycott against British goods and against British repression, the lower classes set up revolutionary committees called Committees of Correspondence (Rees 1999). These were mass meetings of ordinary people making decisions democratically about the way forward and the actions to achieve their decisions, for example to enforce the boycott and to advance the agitation against the British (Rees 1999). Edward Countryman (1989, p. 102) goes so far as to say that '[b]etween 1774 and the summer of 1776 those committees did in New York what similar bodies would do in Paris between 1789 and 1793 and Russia in 1917.'

Given the different class interests, different demands and actions arose before and during the revolution. The most radical of the time, people like Thomas Paine, wrote and spoke in terms ordinary people could and did understand about freedom and equality but this had to be viewed through the prism of the societal development at the time, the classes making up the revolution and their relative strengths. The most radical demands for redistribution and mass democracy came not unnaturally from below, from those poor and labouring masses inspired by the calls from above for democracy and freedom. Even then, many radicals were committed 'to the ownership of productive property as the means of self-determination and freedom' (Rosswurm 1987). This reflected the relatively young age of capitalism in the US and the economic immaturity and class position of the working class and others of the lower sort.

Because the revolution was in part couched in terms of representation, this basic democratic demand inspired the poor and white labouring classes to fight for its realisation. The demands of the real radicals and revolutionaries during the American Revolution went far beyond progressive and equitable tax to demands for a deepening of democracy and a sharing of property that if implemented would threaten the very 'democracy' and free market capitalist society the rich American elite wanted. There were in reality two revolutions - against British rule and against the ruling elite (Petersen 2011). The political revolution in the rich elite's view had to remain a political revolution against the British and not a social revolution by and for the lower sort.

The first constitution, the Articles of Confederation, begun in 1776, but only finally adopted in 1781, was inadequate for the new nation. The articles did not enable the men of property to either trade adequately, defend the country or establish their rule over the masses (Ladenburg 2007). One of the major problems was, as George Washington identified, 'no money' (Maier 2010, p. 11-13).

With the new Constitution in 1791 the elite could finally re-establish control and impose their version of democracy, a system of representation that not only excluded blacks, women and Native Americans but also excluded many of the poor and working class. These were the very people who had joined the armies of rebellion to defeat British rule. Their social role as subservient classes and their focus on the British enemy meant that the American Revolution 
would remain a political revolution and did not become a social revolution, although at times it threatened to.

The demands of the real radicals and revolutionaries for tax justice and equity were a subset of, and hence an important part of, their democratic demands. The tax spark for revolution was but one of many sparks which lit the fuse of rebellion among ordinary Americans from the lower classes and middle class and inspired them to rise up against the economic and political oppression of British capital and the British state. Their class and political immaturity consigned them to replacing one set of economic and political oppressors for another. The Revolution gave a glimpse of an alternative world but the leadership snuffed that out with unity, the unity of the exploited classes with their exploiters. The spark spluttered out.

The taxes the new ruling elite in power imposed show this perfectly. The new country had massive debts from the Revolution. The new rulers imposed crippling taxes on the lower sort to pay those debts. One of the sparks of the revolution now became a blow torch to the belly of the foot soldiers of the revolution. They responded. For example in what became known as Shays Rebellion, farmers in Western Massachusetts refused to pay exorbitant taxes and then resisted attempts to take their land and homes for non-payment (Zinn 2001). It sparked rebellions in other states, including Pennsylvania, Maryland, South Carolina and New Jersey. The political impact was that the Founding Fathers realised they needed, as Zinn (2001, p. n.p.) puts it, 'a strong central government ...to maintain law and order against unruly dissidents, slave rebels, and Indians'. Taxation became or rather remained a creature of class rule, used now by the newly victorious political and economic elite to further burden the lower sort.

\section{Conclusion}

Tax has been a spark for a number of the great rebellions, including as I have shown the American Revolution. That revolution involved not just the ruling class and disputes within that class but has also involved the ruled - ordinary people, including farmers, artisans and workers rebelling against the burden taxes placed on them and more generally the injustice of society and their lack of a say in it. In this the battle over tax represented and reflected the battle for democracy and, more generally, the battle between classes.

Democracy is not only about having a say in what taxes are levied and where the revenue is spent, although that is an important component of the march of democracy and the uprisings tax has helped provoke. Our investigation has not just been about political democracy. It has also touched on economic democracy and challenges to the exploitative nature of class society, reflected in the tax battles. These challenges are often couched in terms of representation or anger against the imposition of taxes that cut the living standards of those who labour in the fields or factories.

These dynamics are not just American - and they are not just of the past.

My hope is that we now have the inspiration to begin in-depth studies of our own current tax systems and the class struggles and crises that produced them. The history of tax from below in our own countries awaits our discovery. 


\section{References}

British Library (n.d.). 'A timeline of the American Revolution from 1763 - 1787' <http://www.bl.uk/onlinegallery/features/americanrevolution/timeline.html> (last viewed 2 February 2017.)

Countryman, E. (1989). A People in Revolution: The American Revolution and Political Society in New York, 1760-1790, Norton Paperback, New York.

Countryman, E. (2003). The American Revolution, MacmillanFranklin, J.H. (1947). From Slavery to Freedom, McGraw-Hill, New York.

Harman, C. (2008). A People's History of the World: From the Stone Age to the New Millennium, Verso, London.

Jefferson, T. (1774). 'A Summary View of the Rights of British America', The Avalon Project, Documents in History, Law and Diplomacy, Yale Law School, New Haven, CT <http://avalon.law.yale.edu/18th_century/jeffsumm.asp> (last viewed 13 February 2017).

Ladenburg, T. (2007). 'Writing the US Constitution - A Simulation', Digital History vol 23 <http://www.digitalhistory.uh.edu/teachers/lesson_plans/pdfs/unit2.pdf> (last viewed 14 February 2017).

Maier, P. (2010). Ratification: The People Debate the Constitution, 1787-1788, Simon \& Schuster, New York.

Marx, Karl (1974). Capital Volume III, Progress Publishers, Moscow, originally published 1894.

Miller, J.C. (1959). Origins of the American Revolution, Stanford Publications, Stanford, CA.

Moseley, F. (2012). 'Hostile Brothers: Marx's Theory of the Distribution of Surplus-Value in Volume 3 of Capital', in The Culmination of Capital: Essays on Volume 3 of Capital, G Reuten (ed), Palgrave.

Nash, G.B. (1996). 'Introduction', in The Negro in the American Revolution: With a New Forward by Thad W. Tate and New Introduction by Gary B. Nash, Benjamin Quarles (ed), University of North Carolina Press, Chapel Hill, NC.

Norquist, G.G. (2012). 'Tea, Taxes and the Revolution', Foreign Policy 3 July 2012 <http://foreignpolicy.com/2012/07/03/tea-taxes-and-the-revolution/> (last viewed 12 April 2017).

Passant, J. (2016). 'Cleaning the Muck of Ages from the Windows into the Soul of Tax' British $\begin{array}{lllllll}\text { Journal of American Legal Studies } & \text { vol } & \text { 5, } & 178\end{array}$ <https://www.degruyter.com/downloadpdf/j/bjals.2016.5.issue-1/bjals-2016-0006/bjals2016-0006.pdf> (last viewed 13 February 2017).

Passant, J. (2016). 'Tax and the Forgotten Classes: from the Magna Carta to the English Revolution' Australasian Accounting, Business and Finance Journal vol 10 no 3, pp 67-88 <http://ro.uow.edu.au/aabfj/vol10/iss3/5/> (last viewed 13 February 2017.)

Passant, John (2015). 'Some Basic Marxist Concepts to Help Understand Income Tax', Journal Jurisprudence vol 27, Michaelmas term, 263-312, last viewed 13 February 2017 <http://www.jurisprudence.com.au/juris27/passant.pdf>.

Petersen, J. (2011). 'Class Struggle and the American Revolution' In Defence of Marxism 14 December 2011 <http://www.marxist.com/class-struggle-and-the-american-revolution.htm> 
(last viewed 15 February 2017).

Raphael, R. (2002). A People's History of the American Revolution: How Common People Shaped the Fight for Independence, New Press, New York.

Rees, J. (1999). 'The socialist revolution and the democratic revolution', International Socialism vol Summer, no 2 p 83 <https://www.marxists.org/history/etol/writers/reesj/1999/xx/revolution.htm> (last viewed 14 February 2017.)

Ross, M.L. (2004). 'Does Taxation Lead to Representation?' British Journal of Political Science vol 34 no 2 (April) 229. https://doi.org/10.1017/S0007123404000031

Rosswurm, S. (1987). Arms, Country, and Class: The Philadelphia Militia and 'Lower Sort' During the American Revolution, 1775-1783, Rutgers University Press, New Brunswick and London.

US Declaration of Independence, <http://www.ushistory.org/DECLARATION/document/> (last viewed 12 April 2017).

US Office of the Historian, US Department of State, 'Milestones: 1750-1775 - Parliamentary taxation of colonies, international trade, and the American Revolution, 1763-1775' <https://history.state.gov/milestones/1750-1775/parliamentary-taxation> (last viewed 27 June 2017).

Young, A.B., Raphael, R and Nash, G.B. (2012). 'To begin the world over again' in Revolutionary Founders: Rebels, Radicals and reformers in the Making of the Nation, Alfred B Young, Gary B Nash, and Ray Raphael (eds), Vintage Books, New York, NY.

Zinn, H. (2001). 'The Greatest Generation?' The Progressive vol 1 (August) <http://progressive.org/magazine/greatest-generation/> (last viewed 15 February 2017).

Zinn, H. (2003). A People's History of the United States, HarperCollins, New York. 